\title{
Chemical composition of berry essential oils from Juniperus communis L. (Cupressaceae) growing wild in Republic of Macedonia and assessment of the chemical composition in accordance to European Pharmacopoeia
}

\author{
Floresha Sela, Marija Karapandzova, Gjoshe Stefkov, Svetlana Kulevanova \\ Institute of Pharmacognosy, Faculty of Pharmacy, University "Ss Cyril and Methodius", Skopje, Republic of Macedonia
}

Received: December 2011; Accepted: February 2012

\begin{abstract}
Chemical composition of fifteen samples of juniper essential oil was analyzed using GC/FID/MS method. Thirteen samples of berries were collected on different locations in south-western part, two of them in central-north region of Republic of Macedonia. The essential oils were obtained by hydrodistillation in a Clevenger type apparatus using official method of European Pharmacopoeia. GC/MS analysis revealed 74 identified components. The predominant fractions of the oils were monoterpene hydrocarbons representing 39.11$73.38 \%$. Great variability in the chemical composition and content of some components was observed. The most variable components were $\alpha$-pinene (15.59-43.19\%), $\beta$-pinene (1.65\%-5.35\%), $\beta$-myrcene (2.89\%-26.50\%), sabinene (2.80-11.77\%), and limonene (2.90-4.46\%). In the fraction of oxidized monoterpenes the most abundant was terpene-4-ol (trace $-6.32 \%)$ followed by $\alpha$-terpineol $(0.18-1.63 \%)$. In the sesquiterpene fraction predominant components were: germacrene D (2.76-10.22\%), $\beta$-elemene (1.13-3.40\%) and trans-(E)-caryophyllene $(1.8 \%-4.05 \%)$. Twelve samples of Macedonian juniper oils comply with European Pharmacopoeia chemical composition requirements for juniper oil and three samples did not, due to lower amount of $\alpha$-pinene.
\end{abstract}

Key words: Juniperus communis, Juniper oil, common juniper, Republic of Macedonia

\section{Introduction}

Common juniper, Juniperus communis L. (Cupressaceae) is widely spread throughout the territory of Republic of Macedonia (Micevski, 1998). The berries of this plant are extensively utilized in production of blended teas and other herbal medicinal products, in food industry, as a spice, in production of alcoholic beverages, etc. The cone-berries (Juniperi pseudofructus) are used traditionally to cure cystitis, digestive disorders, in therapy of chronicle arthritis and other indications. They contain essential oil with characteristic conifer-like aroma and bitterly taste. The pharmaceutical and the medicinal use of the juniper

*svku@ff.ukim.edu.mk oil are of multi-purpose: diuretic, antiseptic, digestive, stomachic, antireumathic, etc. (Yarnell, 2002). Antimicrobial (antibacterial and antifungal) activity of the oil was studied in vitro and many data on this issue point out on a strong antimicrobial activity that could be of interest in medicine and other fields (Filipowitz et al., 2003; Stassi et al., 1995; Emami et al., 2007; Pepeljnjak et al., 2005; Asili et al., 2008; Kumar et al., 2009; Miceli et al., 2009; Glisic et al., 2007; Öztürk et al., 2010; Consentino et al., 2003). Juniper oils are used in production of medicinal products with diuretic and antiseptic activity than in food industry, production of alcohol beverages, cosmetic and perfume production, etc.

The yield and the composition of the essential oils of the juniper berries depends on the geographical origin of 
the plant, the maturity of the berries, the age of the plant, the meteorological condition (temperature, insolation, etc.) and other environmental factors (Orav, 2010; Chatzapoulou and Katsiotis 1993, 1995). Therefore the essential oil composition can vary significantly and that is the reason for very wide-ranging the values in European Pharmacopoeia monograph's requirements for characteristic constituents of the juniper oil (Ph. Eur. 7).

The juniper berries and the juniper essential oil are natural drugs that are exported from Republic of Macedonia, for years behind. Until now, there was no detailed study on the chemical composition of Macedonian juniper oil, which led us to the goal of the present research - determination of the chemical composition and possible chemical variability of the juniper essential oils from wild growing plants in the Republic of Macedonia and assessment of the essential oil chemical composition according to the European Pharmacopoeia.

\section{Materials and methods}

\section{Plant material}

The samples of the ripe juniper berries were collected in a late autumn in 2010 on different locations in Republic of Macedonia. The samples were labeled with marks JC1JC15, relating to the name of the nearest city or name of mountain where the collections were made: JC1 - Mavrovo (1); JC2 - Skopje; JC3 - Resen; JC4 - Demir Hisar; JC5 - Prilep, JC6 - Karaorman Mtn.; JC7 - Kicevo (1); JC8 - Kicevo (2); JC9 - Debar; JC10- Mavrovo (2); JC11 Kicevo (3); JC12 - Jakupica Mtn., JC13 - Pelister Mtn., JC14 - Bistra Mtn.; JC15 - Makedonski Brod. Thirteen samples originated from south-western part of the country and two of them were collected from north-central part (Skopje and Jakupica Mtn.). All samples were left to air dry and then put in a paper bags and stored at cool, dry and dark place, until analysis.

\section{Distillation of the essential oils}

The essential oils were isolated by steam-distillation in a Clevenger-type apparatus using the method from European Pharmacopoeia (Ph. Eur. 7). The oils were dried over anhydrous sodium sulfate and stored in vials under refrigeration prior to analysis.

\section{GC/FID/MS analyses}

Essential oil samples were analyzed on Agilent 7890A Gas Chromatography system with flame ionization detector (FID), and Agilent 5975C mass spectrometer (MS) also equipped with capillary flow technology which enables simultaneous analysis of the sample on both detectors. HP$5 \mathrm{~ms}(30 \mathrm{~m} \times 0.25 \mathrm{~mm}$, film thickness $0.25 \mu \mathrm{m})$ capillary column was used. Operating conditions were as follows: oven temperature $60{ }^{\circ} \mathrm{C}(5 \mathrm{~min}), 1{ }^{\circ} \mathrm{C} / \mathrm{min}$ to $80{ }^{\circ} \mathrm{C}(2$ $\min ) ; 5^{\circ} \mathrm{C} / \mathrm{min} 280^{\circ} \mathrm{C}(5 \mathrm{~min})$; flow rate of $1 \mathrm{ml} / \mathrm{min}(\mathrm{He})$; injector $\mathrm{T}=260{ }^{\circ} \mathrm{C}$; FID $\mathrm{T}=270{ }^{\circ} \mathrm{C} ; 1 \mu$ injection volume at split ratio $1: 1$.

The mass spectrometry conditions were: ionization voltage $70 \mathrm{eV}$, ion source temperature $230{ }^{\circ} \mathrm{C}$, transfer line temperature $280^{\circ} \mathrm{C}$ and mass range from 50-500 Da. The MS was operated in scan mode. Identification of the components present in essential oils was made by comparing mass spectra of components in essential oils with those from Nist, Wiley and Adams mass spectra libraries, by AMDIS (Automated Mass Spectral Deconvolution and Identification System) and by comparing literature and estimated Kovat's (retention) indices that were determined using mixture of homologous series of normal alkanes from $\mathrm{C}_{9}$ to $\mathrm{C}_{25}$ in hexane, under the same above mentioned conditions.

The percentage ratio of essential oils components was computed by the normalization method of the GC/FID peak areas and average values were taken into further consideration $(n=3)$.

\section{Results and discussion}

\section{Chemical composition of the essential oils}

By the means of GC/FID/MS method, all 15 juniper oil samples were analyzed and 74 different components were indentified, representing $91.08-99.83 \%$ of the entire oils (Table 1). Monoterpene components were presented in larger amounts in all samples of the oils than sesquiterpenes (Fig. 1.). Beside mono and sesquiterpenes, small amounts of few non-terpene components were identified, such as undecanone-2 and tricyclene (Table 1).

Terpene hydrocarbons represented the most significant part of the oil rather than oxygen containing terpenes (Fig. 2.). Predominate fraction was monoterpene hydrocarbons, representing the most abundant fraction in all oil samples, ranging from $39.11 \%$ (JC13) to $78.38 \%$ (JC14) (Fig. 3).

In the monoterpene hydrocarbons fractions dominated components were: $\alpha$-pinene (15.59 JC9 - 43.19\% JC14), $\beta$-pinene (1.65 JC9 - $5.35 \%$ JC14), $\beta$-myrcene (2.89 JC5 $-26.50 \%$ JC6), sabinene $(2.80$ JC5 - $11.77 \%$ JC6) and limonene $(2.90 \mathrm{JC} 4-4.46 \% \mathrm{JC} 2)$. The oxygen containing monoterpenes were present only from $2.24 \%$ (JC3) $8.00 \%$ (JC9) in all samples. The most abundant was terpene-4-ol, in traces and up to $6.32 \%$ (JC9) followed by $\alpha$-terpineol (0.18 JC3-1.63\% JC3).

The sesquiterpene hydrocarbons were present from $17.45 \%$ (JC14) to $42.25 \%$ (JC14) in all samples (Fig. 3.). The predominant components were: germacrene D (2.76 JC14-10.22\% JC7); $\beta$-elemene (1.13 JC14-3.40\% JC7) and trans-(E)-caryophyllene (1.8 JC10-4.05\% JC5). The oxygen containing sesquiterpenes have appeared with $0.59 \%$ (JC3) to $5.76 \%$ (JC13). The component $\alpha$-cadinol varied from $0.03 \%(\mathrm{JC} 4)$ to $1.13 \%$ (JC13). The mixture $\tau$-murolol $+\tau$-cadinol were presented from $0.07 \%(\mathrm{JC} 15)$ to 


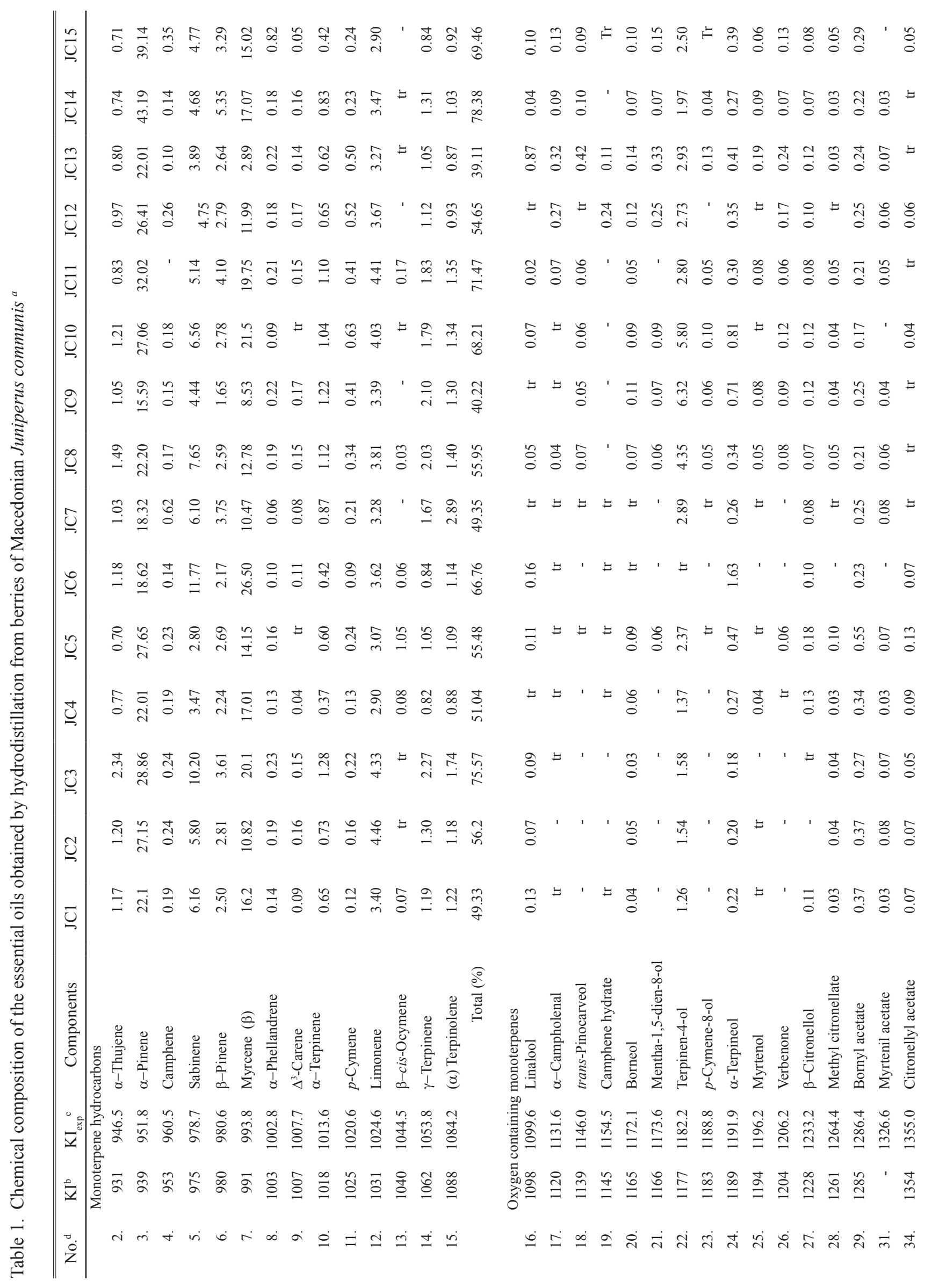

Макед. фарм. билт., 57 (1, 2) 43 - 51 (2011) 


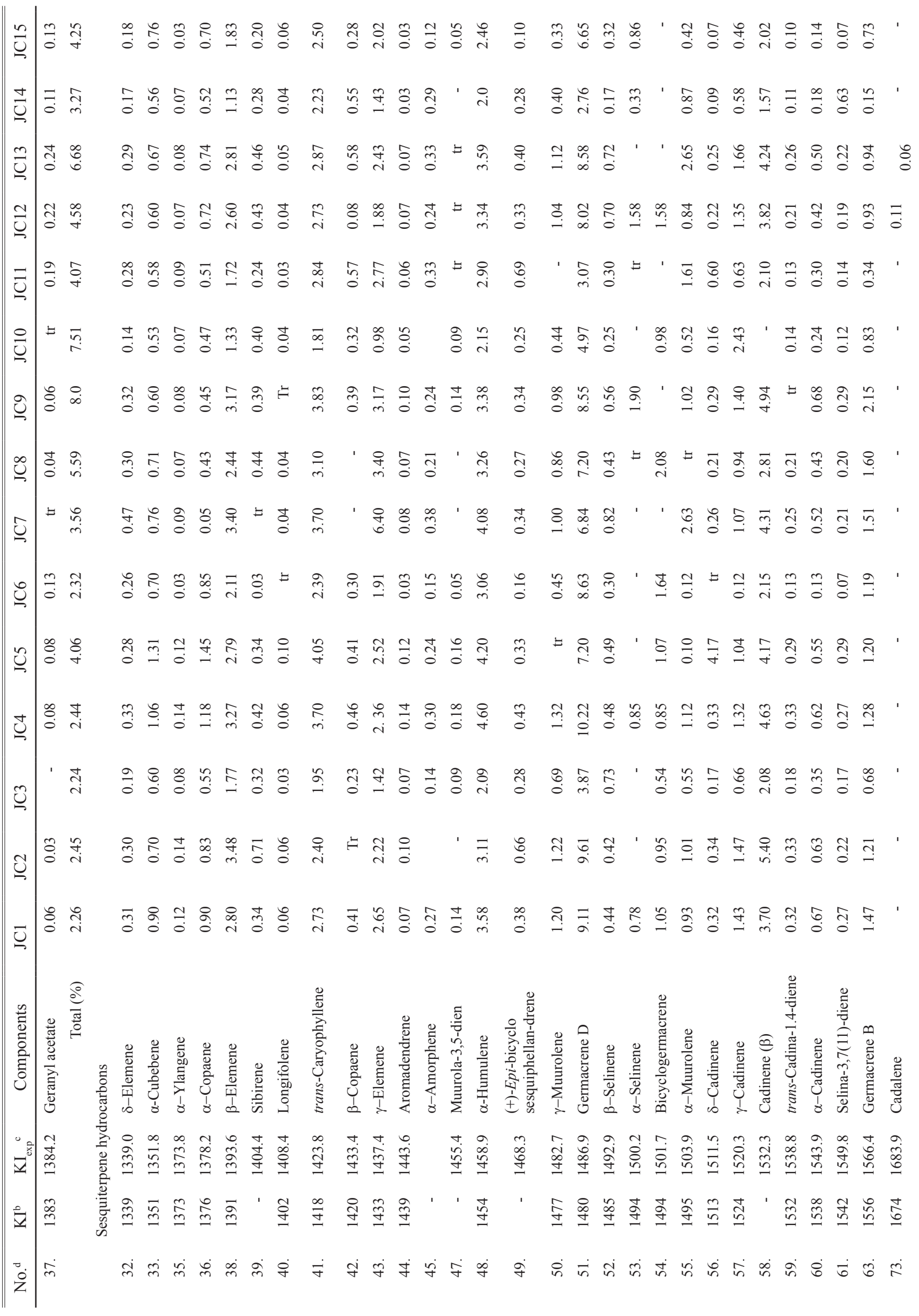

Maced. pharm. bull., 57 (1, 2) 43 - 51 (2011) 


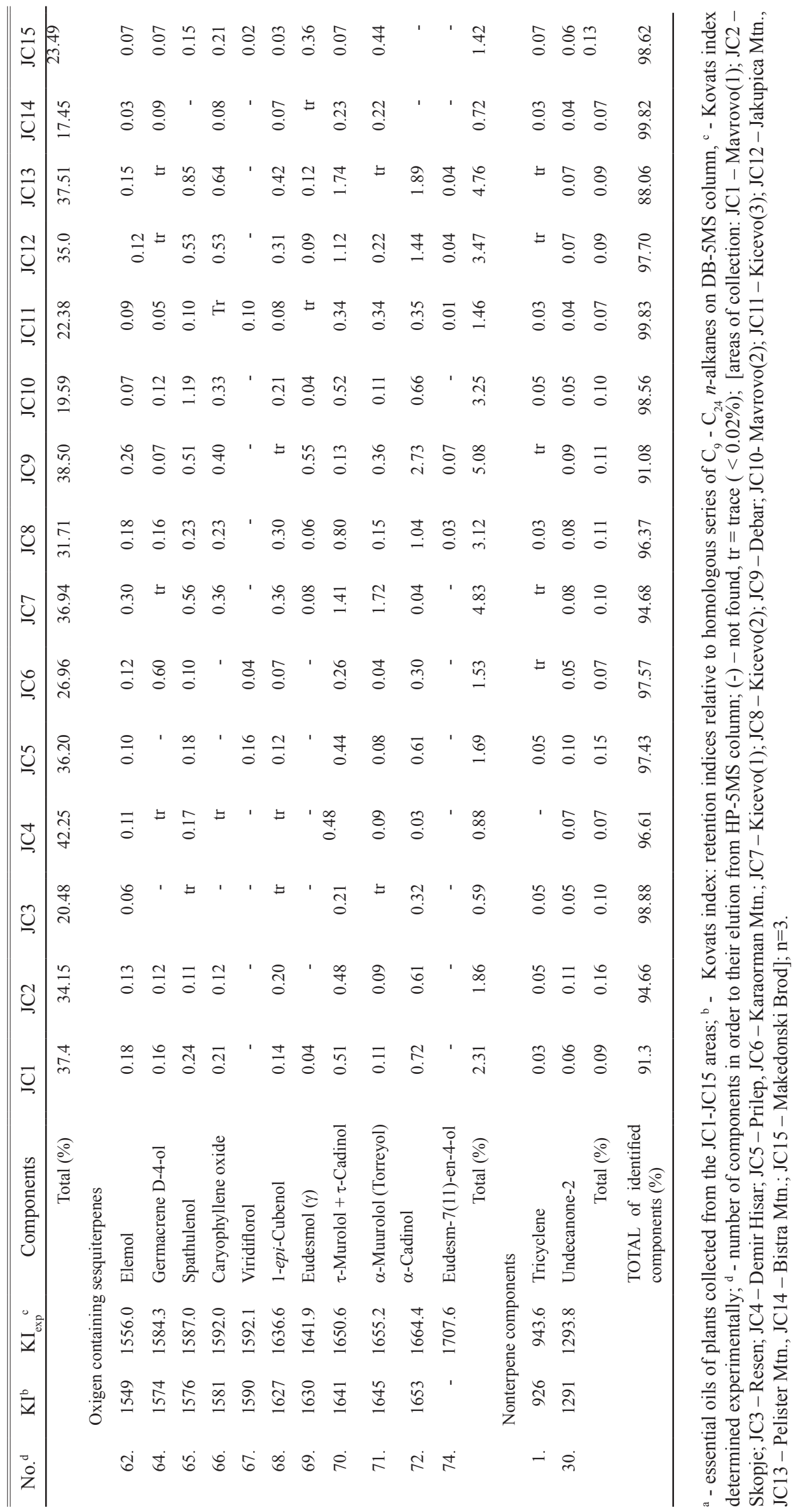

Макед. фарм. билт., 57 (1, 2) 43 - 51 (2011) 


\section{$1.74 \%$ (JC13) (Table 1).}

Analysis of the obtained essential oils from juniper berries from R. Macedonia revealed a great variability in the chemical composition. Considering the components which are required for the quality assessment of juniper oil by European Pharmacopeia monograph, variability in the content of $\alpha$-pinene, myrcene, sabinene, limonene and $\beta$-pinene occur in huge range (Table 1 and 2 ).

Evaluation of the chemical composition and the content of selected components in the investigated essential oils showed that twelve Macedonian samples comply with $\mathrm{Ph}$. Eur. 7 requirements ( $\alpha$-pinene $20-50 \%$; myrcene $1-35.5 \%$, sabinene $<20 \%$, limonene $2-12 \%$; $\beta$-pinene $1-12 \%$; trans (E) caryophyllene $<7 \%$; terpinen-4-ol 0.5-10\%; bornyl acetate $<2 \%$ and $\alpha$-phellandrene $<1 \%$ ). However, three oil samples obtained from the berries from Karaorman (JC6), Kicevo (1) (JC7) and Debar (JC9) contained insufficient amount of $\alpha$-pinene $(18.62 \%, 18.32 \%$ and $15.59 \%$, respectively) nevertheless the amounts of other components were satisfactory. Eventually prepared mixture of equal parts of all fifteen investigated juniper oils, mix oil, should have average percentages of the components that comply with the $\mathrm{Ph}$. Eur. 7 requirements for chemical composition quality (Table 2). This could be a solution for solving problems that appeared on chemical composition of the juniper essential oil from berries originated from different areas of collection. However, for complete assessment of the quality of the Macedonian juniper oils requires further analysis on several physical and chemical characteristics of the oils, set under the section tests as well as other features of the oil mentioned in the Juniper oil monograph.

Differences and the variability in the oil composition of juniper essential oils were reported for the oils originated from different regions in Europe and in America. The main constituents of the oils are pinenes, mostly $\alpha$-pinene which could be present in a wide range, from $27 \%$ in the Greek samples (Chatzopoulou and Katsiotis, 1993), over 28.6-38.2\% in Montenegro (Damjanovic et al., 2006),

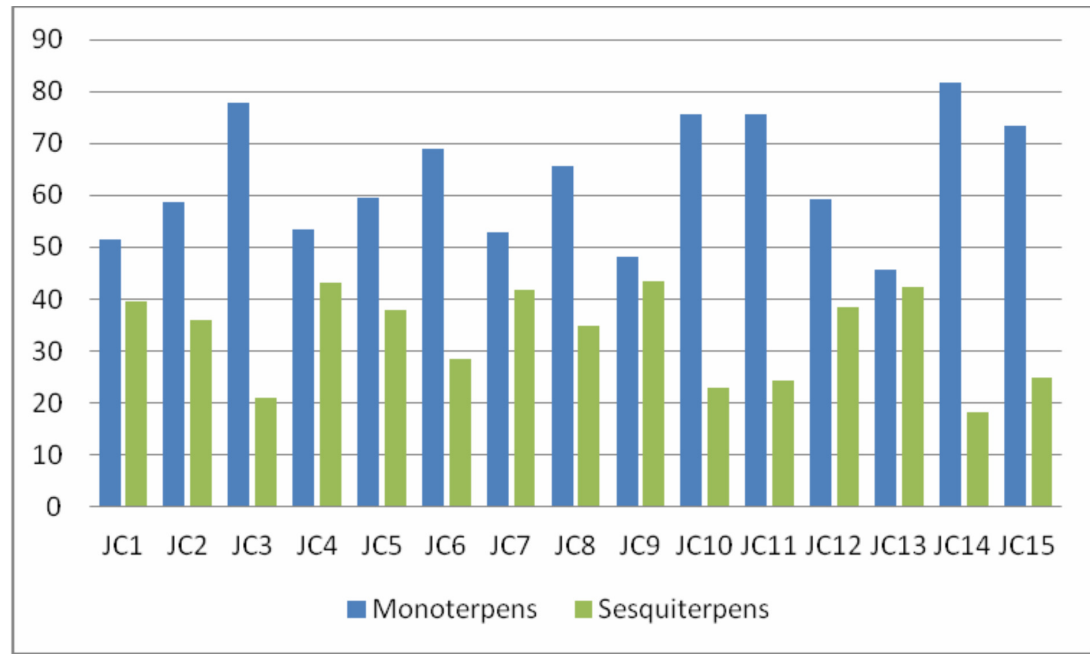

Fig. 1. Main fractions in the essential oils from Macedonian samples of juniper berry (JC1 -JC15 oil samples).

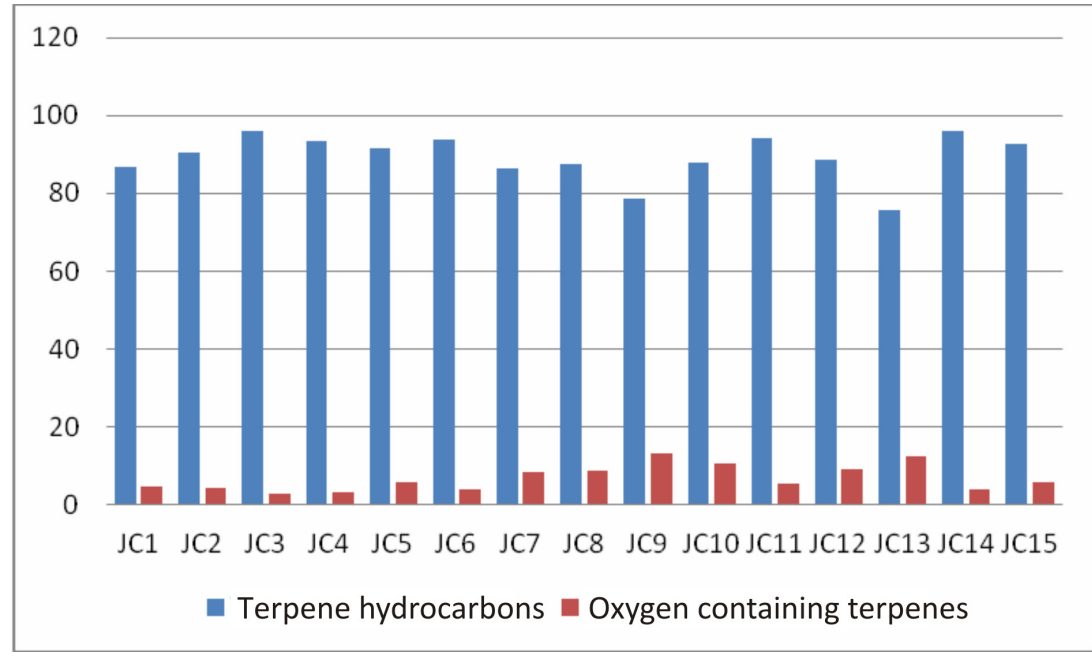

Fig. 2. Terpene hydrocarbons/oxygen containing terpenes ratio in the essential oils of Macedonian juniper berry (JC1-JC15 oil samples). 
Table 2. Variations in the main components composition of the essential oils obtained from berries of Macedonian Juniperus communis

\begin{tabular}{|c|c|c|c|c|c|}
\hline & \multirow[t]{2}{*}{ Components } & \multicolumn{2}{|c|}{$\begin{array}{c}\text { Juniper oils } \\
(\%)\end{array}$} & \multirow[t]{2}{*}{$\begin{array}{c}\text { Ph.Eur. } 7 \\
(\%)\end{array}$} & \multirow[t]{2}{*}{ Score 1} \\
\hline & & Min & Max & & \\
\hline $\begin{array}{l}1 . \\
2 .\end{array}$ & $\begin{array}{l}\alpha \text {-Pinene } \\
\text { Myrcene }(\beta)\end{array}$ & $\begin{array}{l}15.59 \\
2.89\end{array}$ & $\begin{array}{l}39.14 \\
26.50\end{array}$ & $\begin{array}{c}20-50 \\
1-35,5\end{array}$ & $\begin{array}{l}(-) \\
(+)\end{array}$ \\
\hline 3. & Sabinene & 2.80 & 11.77 & $<20$ & $(+)$ \\
\hline 4. & Limonene & 2.89 & 4.46 & $2-12$ & $(+)$ \\
\hline 5. & $\beta$-Pinene & 1.65 & 4.10 & $1-12$ & $(+)$ \\
\hline 6. & trans (E)-Caryophyllene & 1.81 & 4.05 & $<7$ & $(+)$ \\
\hline 7. & Terpinen-4-ol & $\operatorname{tr}$ & 6.32 & $0.5-10$ & $(-)$ \\
\hline 8. & Bornyl acetate & 0.17 & 0.37 & $<2$ & $(+)$ \\
\hline 9. & $\alpha$-Phellandrene & 0.09 & 0.82 & $<1$ & $(+)$ \\
\hline
\end{tabular}

$(+)$ - fulfilled monograph's requirements, $(-)$ - not fulfilled monograph's requirements

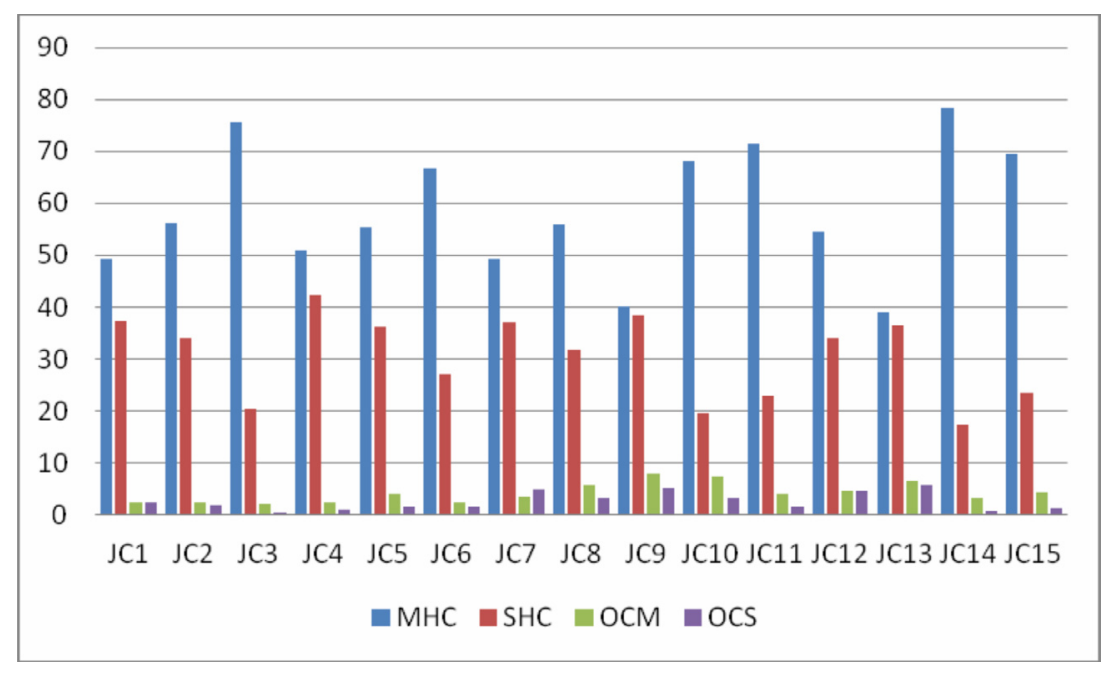

Fig. 3. The abundance of MHC - monoterpene hydrocarbons, SHC - sesquiterpene hydrocarbons, OCM - oxygen containing monoterpenes and OCS - oxygen containing sesquiterpenes in essential oils from Macedonian juniper berry (JC1 - JC15 oil samples).

and up to $46,63 \%$ in the Iranian samples (Rezvani, 2010). Other important components such as sabinene, germacrene $\mathrm{D}$, myrcene, $\beta$-pinene and limonene were found in higher amounts in juniper oil (Chatzopoulou and Katsiotis, 1993; Orav et al., 2010; Pepeljnjak et al., 2005). Terpine-4-ol is an important constituent of juniper oil, usually considered to be responsible for the diuretic effect of the oil. Its content in juniper oil can be variable and it was attained in small amount of $1.37 \%$ in Greek samples and $2.86 \%$ in samples from Iran (Chatzopoulou and Katsiotis, 1993; Rezvani, 2010).

\section{Conclusion}

GC/FID/MS analysis of the chemical composition of fifteen samples of juniper essential oils from berries of wild growing juniper in Republic of Macedonia revealed 74 identified components that represent $91.08-99.83 \%$ of all of the samples. The predominant fraction of the oils was monoterpene hydrocarbons representing 39.11-73.38\%. Great variability in the chemical composition and especially in the content of some components was observed. The most variable were $\alpha$-pinene $(15.59-43.19 \%), \beta$-pinene (1.65\%-5.35\%), $\beta$-myrcene $(2.89 \%-26.50 \%)$, sabinene (2.80-11.77\%), and limonene $(2.90-4.46 \%)$. In the fraction of oxygen containing monoterpenes the most abundant was terpene-4-ol, in traces and up to $6.32 \%$ followed by $\alpha$-terpineol $(0.18-1.63 \%)$. In the fraction of sesquiterpene the predominant components were: germacrene D (2.76-10.22\%), $\beta$-elemene (1.13-6.40\%) and trans-(E)caryophyllene $(1.8 \%-4.05 \%)$. Assessment of the chemical composition quality of the oils in accordance with the European Pharmacopoeia monograph of juniper oil showed that twelve Macedonian samples comply with Ph. Eur. 7 requirements and three samples possess lower amounts of $\alpha$-pinene, under the requested level of $\min 20 \%$. 


\section{References}

Asili, J., Emami, S.A., Rahimizedeh, M., Fazly-Bazzaz, B.S., Hassanzadeh, M.K., 2008. Chemical and antimicrobial studies of Juniperus communis subsp. hemisphaerica and Juniperis oblonga essential oils, J. Essent.oil - Beraing Plants, 11 (1), 96-105.

Chatzapoulou, P. , Katsiotis, S.T., 1995. Procedures influencing the yield and the quality of the essential oil from the Juniperus communis L. berries, Acta Pharm. Helvetiae 70, 247-253.

Chatzapoulou, P., Kastsiotis, S.T., 1993. Study of the essential oil from Juniperus communis 'berries' (cones) growing wild in Greece, Planta Med. 59 (6), 554-556.

Consentino, S., Berra, A., Pisano, B., Cabizza, M., Pirisi, F.M., Palmas, F., 2003. Composition and antimicrobial activity of Sardinian Juniperus oils against foodborne pathogens and spoilage microorganisms, J. Food Prot. 66 (7), 1288-1291.

Emami, S.A., Javadi, B., Hassanzadeh, M.H., 2007. Antioxidant activity of the essential oils of different parts of Juniperus communis L. subsp. hemisphaerica and Juniperus oblonga, Pharmaceutical Biology 45 (10), 769-776.

European Pharmacopoeia, 2011. $7^{\text {th }}$ edition, Council of Europe, Strasbourg, 1160-1161.

Filipowicz, N., Kaminski, M., Kurlenda, J., Asztemborska, M., Ochocka, J.R., 2003. Antibacterial and antifungal activity of juniper berry oil and its selected components, Phytother. Res. 17 (3), 227-231.

Glisic, S.B., Milojevic, S.Z., Dimitrijevic, S.I., Orlovic, A.M., Skala, D.U., 2007. Antimicrobial activity of the essential oil and different fractions of Juniperus communis L., and a comparison with some commercial antibiotics, J. Serb. Chem. Soc. 72 (4), 311-320.

Kumar, P., Prasad, R., Chandra, H., Bhatt, R.P., Sati, O.P., Invitro antibacterial activity of Juniperus communis L. against bacterial pathogens, Environ. Conserv. J. 10 (3), 101-104.

Miceli, N., Trovato, A., Dugo, P., Cacciola F., Donato P., Marino, A., Bellinghieri, V., La Barbara, T.M., Gljvenc, A., Taviano, M.F., 2009. Comparative analysis of flavonoid profile, antioxidant and antimicrobial activity of the berries of Juniperus communis L. var. communis and Juniperus communis L. var. saxatilis Pall, from Turkey, J. Agric. Food. Chem. 57 (15), 6570-6577.

Micevski, К., 1998. Флора на Република Македонија. Т. 1, св. 4, Македонска академија на науките и уметностите, Скопје, 81-84.

Orav, A., Kailas, T.,Müürisepp, M., 2010. Chemical investigation of the essential oil from berries and needles of common juniper (Juniperus communis L.) growing wild in Estonia, Nat. Prod. Res. 24 (19), 1789-1799.

Öztürk, M., Tümen, İ., Ugur, A., Aydogmuş-Öztürk, F. and Topçu, G., 2011. Evaluation of fruit extracts of six Turkish Juniperus species for their antioxidant, anticholinesterase and antimicrobial activities. J. Sci. Food Agric. 91: 867-876. DOI: 10.1002/jsfa. 4258.

Pepelnjak, S., Kosalec, I., Kalodzera, Z., Blazevic, N., 2005. Antimicrobial activity of juniper berry essential oil, Acta. Pharm. 55, 417-422.

Rezvani, S., 2010. Investigation and comparison of Juniperus polycarpos \& Juniperus communis essential oil from Golestan Province, J. Med. Plants 9 (33), 83-89.

Stassi, V., Verykokidou, E., Loukis, A., Harvala, C., Philianos, S., 1995. The antimicrobial activity of the essential oils of four Juniperus species growing wild in Greece, Flav. Fragr. J., 11 (1), 71-74. DOI 10.1002/(SICI)10991026(199601)11:1<71::AID-FFJ536>3.0.CO;2-9.

Yarnell, E., 2002. Botanical medicines for the urinary tract, World J. Urol. 20, 285-293. DOI 10.1007/s00345-002-0293-0.

Хемиски состав на етерично масло изолирано од бобинките од Juniperus communis L. (Cupressaceae) кој самоникнато расте во Република Македонија и проценка на хемискиот состав на маслото во согласност со Европската фармакопеја

\author{
Флореша Села, Марија Карапанџова, Ѓше Стефков, Светлана Кулеванова*
}

Институт за Фармакогнозија, Фармацевтски факултет, Универзитет ”Св. Кирил и Методиј”, Скопје, Македонија

Клучни зборови: Juniperus communis, етерично масло од смрека, смрека, Република Македонија.

Анализата на хемиски состав на петнаесет примероци на етерично масло изолирано од смрека е направена со помош GC/FID/MS метод. Тринаесет примероци на бобинки беа собрани на различни локации во југо-западниот дел на Р. Македонија, а останатите два во централно-северенот регион. Изолацијата на етерични масла е направена со официјалниот метод на Европската фармакопеја со дестилација со водена пареа со користење на апаратурата 
по Клевенџер. Co GC/MS анализа идентификувани се вкупно 74 компоненти. Доминантната фракција на маслата се монотерпенските јаглеводороди и истите сочинуваат $39,11-73,38 \%$ од вкупното етерично масло. Утврдена е голема варијабилност во хемискиот состав и во содржината на определени компоненти. Најголеми варијации се забележани кај компонените како што се $\alpha$-пинен $(15,59-43,19 \%), \beta$-пинен $(1,65 \%-5,35 \%), \beta$-мирцен $(2,89 \%-26,50 \%)$, сабинен $(2,80-11,77 \%)$ и лимонен $(2,90-4,46 \%)$. Во фракцијата на монотерпените со кислород, најзастапен е терпен-4-ол $(6,32 \%)$ заедно со $\alpha$-терпинеол $(0,18-1,63 \%)$. Во сесквитерпенската фракција, најдоминантни компоненти се: гермакрен D $(2,76-10,22 \%), \beta$-елемен (1,13-3,40\%) и trans-(Е)-кариофилен (1,8\% - 4,05\%). Дванаесет примероци на етерично масло изолирано од плодови од македонска смрека одговараат на барањата на Европската фармакопеја за хемискиот состав на етерично масло од смрека, додека три примероци не одговараат на овие барања поради помалата содржина на $\alpha$-пиненот. 
